\title{
Ethnologies
}

\section{The challenge of creative tourism}

\section{Greg Richards}

Volume 38, numéro 1-2, 2016

Créativité et médiation en tourisme et en patrimoine

Creativity and mediation in tourism and heritage

URI : https://id.erudit.org/iderudit/1041585ar

DOI : https://doi.org/10.7202/1041585ar

Aller au sommaire du numéro

\section{Éditeur(s)}

Association Canadienne d'Ethnologie et de Folklore

ISSN

1481-5974 (imprimé)

1708-0401 (numérique)

Découvrir la revue

Citer cet article

Richards, G. (2016). The challenge of creative tourism. Ethnologies, 38(1-2), 31-45. https://doi.org/10.7202/1041585ar

\section{Résumé de l'article}

La créativité est à la fois le ciment qui lie les blocs de fondation du tourisme et le lubrifiant qui fait évoluer le système touristique vers de nouvelles dimensions. Dans cet article, les auteurs tentent de démontrer en quoi la créativité est essentielle à notre compréhension du tourisme. Ils démontrent en particulier la façon dont même les produits touristiques traditionnellement " acquis » tels que la culture et la nature ne sont pas acceptés passivement par les touristes : les touristes créatifs s'engagent dans la coproduction de leurs expériences naturelles/culturelles en tant que touristes. Pour la « classe créative ", l'authenticité réside dans les expériences que l'on crée ensemble car ils ne la voient pas résider dans les objets de consommation comme si elle en était une partie inhérente. Cependant, pour que le système touristique soit viable, le besoin de changement qu'éprouve la créativité devrait être tempéré par un besoin correspondant de continuité. Par conséquent, les entreprises touristiques, pour réussir, doivent parvenir à un équilibre dynamique entre continuité et changement.
Ce document est protégé par la loi sur le droit d'auteur. L’utilisation des services d’Érudit (y compris la reproduction) est assujettie à sa politique d'utilisation que vous pouvez consulter en ligne.

https://apropos.erudit.org/fr/usagers/politique-dutilisation/ 


\section{THE CHALLENGE OF CREATIVE TOURISM}

\section{Greg Richards \\ Tilburg University}

In the past forty years the relationship between culture, economy and society has changed beyond recognition. Culture has grown beyond its original socialisation role to become the oil of the new economy and a vital reservoir of symbolic resources that feeds tourism production and consumption. Heritage has emerged as a force for urban and rural renewal and preservation, becoming a global industry in its own right.

More recently the growth of the creative economy has been chracterised by the increasing intangibilisation of culture and heritage, as they have become vital markers of symbolic value. In the field of tourism, this change has been signaled by the continued growth of cultural tourism, and the recent fragmentation of cultural tourism into a number of sub-fields, including film tourism, gastronomic tourism, festival tourism, etc. (Richards, 2001; Hjalager and Richards, 2002).

The growing importance of creativity and intangible heritage in tourism has also stimulated the development of a specific sub-field of 'creative tourism' (Richards and Raymond, 2000). Creative tourism arguably represents a departure from traditional models of cultural and heritage tourism, moving away from tangible heritage as the key asset towards creative and symbolic capital.

This paper examines the development of creative tourism in recent years, tracing its trajectory from a sub-field of cultural tourism towards an emerging field and philosophy of tourism.

\section{The massification of cultural tourism}

Tourism has always involved the consumption of culture. Since antiquity, people have travelled to learn more about other cultures and about civilisations different from their own. In the context of the Grand 
Tour this was very literally an educational journey, the finishing touch to an aristocrat's education.

The Grand Tour solidified a system of meaning based on the Classics and the Renaissance, which during the $18^{\text {th }}$ and $19^{\text {th }}$ centuries was physically underpinned by the emerging system of national museums (Richards, 2001; see also McManus, 2000). The tourist toured these 'factories of meaning' in search of the highlights of a culture, the authorised version (MacCannell, 1976).

With the rise of mass tourism, the cultural system of museums and monuments became the backbone of tourist consumption as people gathered the symbols of the countries they visited. More attention began to be paid to the increasing linkage of tourism, culture and heritage in the 1980s, when Hewison (1987) famously linked the 'heritage boom' in the UK to the declining status of Britain on the global stage. Real power was replaced by a celebration of past glories, reinforced by a Thatcherite government keen to emphasise national heritage. The political marriage of heritage and tourism was marked in concrete terms by the creation of a Ministry of National Heritage in 1992, which had responsibility for culture (a taboo term for the far right), heritage (an acceptable form of culture) and tourism. A number of parallel developments were observable elsewhere, including the rise of ecomuseums in Europe and the creation of preservation districts in North America.

Linking culture and tourism was seen as a synergy - culture provided the attractions that would generate tourism, and tourism would provide the money required to support culture. A new logic for the expansion of culture and cultural attractions emerged, driven largely by economic arguments. This would later be identified as the emergence of the 'symbolic economy' (Lash and Urry, 1994). By the 1990s, the growth in Museum supply in Europe actually outstripped the growth in tourism demand (Richards, 1996), but this did little to stem the flow of new projects. Culture was not just 'good' in educational terms, but it was considered an acceptable form of tourism development, particularly when contrasted with the negative impacts of mass beach tourism.

But cultural tourism continued to develop apace in the 1990s, arguably accounting for $40 \%$ of global tourism by the end of that decade (Richards, 2007). Short city trips became one of the staples of the tourism market, and culture was an obvious mainstay of the urban tourism product (ETC, 2005). The growing crowds flocking to cultural 'honeypots' around the 
world led to problems of overcrowding and deterioration of the cultural sites themselves.

These problems were particularly acute in the historic city centres in Europe, and so it was not surprising that critical voices began to be heard about the development of cultural tourism there. In particular, the development of tourism in Venice came to epitomise the problems of 'mass cultural tourism'. Russo's (2002) analysis of tourism in Venice indicated that the city was suffering from a negative 'vicious circle' of tourism development, with a growing number of day visitors staying for a shorter time in the city leading to a deterioration of the tourism product and the cultural fabric, resulting in lower value tourism and a lack of investment and an extension of the tourism area.

The answer to these problems lay according to some commentators in the development of 'quality tourism'. However, as Dahles (1998) pointed out, such debates often reflected elitist struggles around the 'right to the city', with different groups claiming urban spaces as their own and labelling visitors and tourists as outsiders who were seen as having fewer rights. A different, but perhaps no less elitist approach was adopted by advocates of smaller scale, 'alternative' tourism models (Butler, 1990). These often advocated a bottom-up approach to development, with local communities having an active role in determining the style and scale of tourism development. Culture was often an important element in such schemes, because it provided the link between local communities (who were seen as 'having' culture to exhibit) and visitors, who had a more universal interest in 'culture' as something to be consumed.

\section{The rise of creativity}

The crisis of cultural tourism at the turn of the century coincided with growing competitive struggles between cities and regions for resources and attention in a globalising economy. As Turok (2009) suggests, one of the key issues for many places in their attempt to gain competitive advantage was the need to become distinctive, and therefore to attract attention (Richards, 2013).

The irony is that in their search for distinctiveness, many places adopted similar strategies, such as the creation of iconic structures, organising mega events or 'heritage mining' (Richards and Wilson, 2006). This led to a form of serial reproduction of culture, which, arguably, added to the growing problems of cultural tourism development. 
This created pressure to look for alternatives to existing models of tangible heritage exploitation. As the ETC report City Tourism $\mathbb{E}$ Culture - The European Experience pointed out in 2005, it was not enough to have culture; you also needed to have creative assets as well. This was because the shape of consumer demand was also beginning to change, with people increasingly seeking engaging experiences rather than the passive spectacle provided by the 'cathedrals of consumption' such as theme parks, shopping malls or museums (Ritzer, 1999). The need for tourism and leisure producers to generate more engaging experiences was encapsulated in the notion of the 'experience economy' (Pine and Gilmore, 1999). They suggested that growing competitive pressures in the service economy was forcing producers to look for higher value forms of transaction with consumers, which arguably could be found in the production of more holistic 'experiences'. Experience production began to dominate the tourism scene, and the development of cultural and heritage experiences was particularly rapid around the turn of the current century (Richards, 2001b).

But far more than experiences simply representing more sophisticated offerings from producers, the increased demand for experiences was also based on a growing need for individual creativity. Not only did consumers want to be presented with experiences shaped for them by producers (first generation), but they also wanted to be involved in the 'co-creation' of experiences (second generation experiences). The drive for creative expression was also seen in the growth of creative occupations, to the extent where Richard Florida (2002) identified the rise of a 'creative class'. The creative class were arguably attracted by the atmosphere and other 'soft' production factors of places, and so in order to attract creative people, places themselves had to be creative.

From the demand side and the production side, therefore, creativity became a mantra. Cities needed to be creative in order to attract the creative class, who in turn would make the cities more attractive for tourists and residents. The convergence of demand and supply factors led to a growing demand for creative experiences in tourism. Although such experiences had long been an informal part of tourism, it was only in 2000 that this segment of tourism was identified and defined as 'creative tourism' by Richards and Raymond (2000: 18). They defined creative tourism as:

Tourism which offers visitors the opportunity to develop their creative potential through active participation in learning experiences which are characteristic of the holiday destination where they are undertaken. 
This definition suggests an important shift from traditional forms of cultural or heritage tourism, in that it argues for a creative role for both producers (who have to be creative in using resources to develop active participation) and tourists (who need to engage creatively with the destination). This is essentially a recipe for what later became known as 'co-creation' (Binkhorst and den Dekker, 2009) of tourism. In contrast to more conventional forms of cultural tourism, for example, creative tourism also implies a more active involvement of the tourist in the culture and creative life of the destination. The implication of active involvement and the development of learning also means that creative tourism is likely to remain relatively small scale, distinct from the current trend towards 'mass cultural tourism' at important cultural sites (Russo, 2002).

Arguably, creative tourism has a number of potential advantages over traditional forms of tourism:

- Because it is based on intangible resources, it can be more sustainable than traditional forms of cultural or heritage tourism.

- Because it does not depend on physical structures, the infrastructure investment needs are often lower.

- Creativity is a mobile resource that is also present in all locations and layers of society, allowing more equitable participation.

- Creative tourism promotes interaction between locals and visitors. The roles of both actors are also more equitable, because the skills and know-how that are sought by tourists reside in the local population, who can therefore adopt the role of teacher rather than of mere service provider.

Over the past decade, many places have adopted creative tourism development models (Richards and Wilson, 2007; Richards, 2013; OECD, 2014). In some cases this was more of a philosophical stance, particularly where traditional models of tourism could arguably be augmented by adding a creative dimension. In other cases, specific institutions arose to guide the development and marketing of creative tourism. The following two sections deal with the development of creative tourism as a philosophy and as a practical field of policy and marketing development.

\section{Consuming creative tourism}

The basic orientation of many creative tourism programmes can be summarised in a saying of Confucius: 'I hear and I forget. I see and 
I remember. I do and I understand.' This was the basic philosophy developed by Crispin Raymond in the Creative Tourism New Zealand programme which started in 2003 . This approach places the emphasis on creative activity as a means of engaging participants and developing a link between producers and consumers. Many different workshops were provided, including bone carving, rush weaving, local gastronomy and pottery. Although the original model of developing a marketing platform for local experience providers was not successful in New Zealand (largely due to a limited tourist market - Raymond, 2007), the programme still runs, and was dubbed 'top choice activity in Nelson' by the Lonely Planet New Zealand Guide in 2012/13.

In the last few years a growing body of work has developed on the engagement and learning outcomes provided by creative tourism experiences. For example, Jusztin (2012) examined the creative experiences of tourists visiting museums using the 'JOHARI window' model, which indicates that active involvement enhances the memory of tourism experiences. Messinio (2012:53) found that creative processes can benefit both producers and consumers:

creativity is certainly a resource that can strengthen, diversify and enrich the tourist planning process by linking the desires, demands and needs of both consumers and producers. To create forms of tourist creative production and consumption means offering traditional heritage resources in new terms, bringing in new ideas, new ways of interpreting heritage and place through experiential strategies that go beyond the moment of consumption and which can provide links to all the creative resources put into play.

In their studies of creative tourism experiences at a pottery in Taiwan, Hung et al. (2014) found that there was a significantly positive relationship between creative experiences and memorability. They also suggested that there is a need to build a creative tourism experience and behaviour model. Tan et al. (2014) have contributed to the development of such a model in their study of the taxonomy of creative tourists. Using Q-methodology they identified five distinct groups of creative tourists: 'novelty-seekers, knowledge and skills learners, those who are aware of their travel partners' growth, those who are aware of green issues, and the relax and leisure type.' They found that there were differences in the ways in which individuals view creativity, and their values and concerns in creative experiences. This indicates that creative experiences should be individually crafted with respect to the creative needs of the visitors as well as the creative resources of the destination. 
In her analysis of creative tourism experiences in Barcelona, Ilincic (2014) found that tourists displayed openness and willingness to learn about Spanish cuisine, expressing motives related to learning, novelty or love for cooking. The interest of participants was increased by interpretation and interactions with chefs and local residents, and through their own active involvement. The tourists saw these creative experiences as being authentic and memorable, because 'the cooking activity to be closely related to destination visited, stating importance of experiencing country's gastronomy while actually being in a real Catalan setting.' These experiences were also seen by participants as being different from other experiences they had in the city, indicating the potential for creative tourism to create distinction for destinations. However, no deep personal transformation was involved.

\section{Producing creative tourism}

The recent development of creative tourism has underlined a great variety of different approaches that usually reflect the local context and needs. As outlined in the OECD report on Tourism and the Creative Economy (2014), creative tourism development has occurred in three basic forms: private sector led initiatives, public sector led initiatives and public-private sector partnership.

\section{Private sector led}

As outlined above, Creative Tourism New Zealand (CTNZ) was the first creative tourism programme, and this was developed as a private initiative by Crispin Raymond and a number of collaborators on New Zealand's South Island. In spite of many attempts, this programme never gained public sector funding, and therefore found it difficult to maintain the central activities (Raymond, 2007)

However, Creative Tourism New Zealand did create a significant legacy in terms of the experience developed and the demonstration effect that it had on other projects around the world. For example Elena Paschinger, one of the volunteers who worked for CTNZ went on to found Creative Tourism Austria (see below), and the UNESCO creative tourism initiative led by Santa Fe also owed a big debt to the pioneering work of Crispin Raymond (see below and Wurzburger et al., 2009).

Creative Tourism Barcelona (CTB) was founded in 2005 on the initiative of FUSIC, a cultural foundation based in the Catalan capital. As Couret (2012) explains, in contrast to CTNZ, the Barcelona programme did 
obtain some public sector funding in the early years, basically by promoting Catalan culture and language. However, the programme has continued basically as a private sector initiative, and now works actively as a kind of creative tourism broker, providing creative experiences and contacts for people visiting Barcelona.

Coming from the voluntary sector, FUSIC managed to fill an important gap, as Couret (2012: 132) explains:

there is no public organization or private company that could provide creative tourists with personalized information or services such as - in the case of a youth choir for instance - a venue adapted to their artistic needs and their budget.

The work of CTB has also spurred more commercial providers to adapt their offer by adding creative elements to their projects. Thus again, the presence of a creative tourism platform seems to have a more general effect across the tourism sector as a whole.

The international Creative Tourism Network ${ }^{1}$ was founded by CTB in 2010 with partners from Paris and Rome with support from the European Commission through the Culture Programme. This was launched at an international conference in Barcelona in 2010, which also spawned a range of papers on creative tourism (Richards and Marques, 2012). This conference was later followed up with a second conference in Paris in 2012 (see below), and since the launch more than 25 destinations and organisations have joined the CTN.

Creative Tourism Austria ${ }^{2}$ was founded by Elena Paschinger and Hermann Paschinger and has a more commercial orientation, bringing together hotels with creative offerings and many other private sector service providers. Elena also writes an interesting blog covering creative tourism experiences around the world ${ }^{3}$.

Creative Iceland is a more recent example of a private sector initiative, again acting as a creative experience broker between those providing creative activities and tourists ${ }^{4}$. There is a wide range of experiences on offer, drawing for example on Iceland's storytelling legacy (elves and hidden people, folklore and wonders) as well as more contemporary creativity (graphic design, fashion, culinary arts).

1. www.creativetourismnetwork.org

2. www.kreativreisen.at/en.html

3. www.creativelena.com/en/

4. creativeiceland.is 
Creative Tourist is a listings service run by Creative Tourist Ltd., a communications agency that works on cultural tourism projects across the UK. According to the website:

creativetourist.com is the UK's only dedicated art and travel site. It began life in Manchester and is expanding across the North; it uncovers the best art and cultural events, and publishes insider guides to some of the UK's most creative destinations.

Alongside these more structured programmes, many small-scale creative tourism offerings have sprung up, taking advantage of the possibilities for peer-to-peer tourism marketing. For example, Pon le cara al turismo ${ }^{5}$ is an initiative of young creatives in Galicia, Spain, who act as guides to the creative assets of the region.

\section{Public sector led}

The development of private sector led creative tourism programmes also inspired the public sector to become more actively involved in a number of destinations.

One of the first major public programmes was Creative Paris, launched at the second CTN conference held in the city in 2012. The Association for the Development of Creativity, Studies and Projects (ADCEP), offered a suite of courses and creative experiences through the portal creativeparis. info, which listed over 400 arts centres and more than 1,000 courses in areas such as photography, multimedia, digital arts, fashion, design, jewellery, culinary arts and gastronomy and literature. The site receives about 10,000 unique visitors per month, $30 \%$ of whom are international.

These workshops are open to amateur artists as well as the general public, and they respond to the recent explosion in individual creative expression, particularly stimulated by digital technology. They also reflect the trend towards "collaborative consumption", such as eating with the locals and home exchange. Such peer-to-peer programmes are now being actively supported by the public sector as a way of attracting 'temporary citizens' from around the world.

In order to support the development of creative tourism in Paris, a series of 'Welcome City Labs' has been established to stimulate co-creation between tourists and residents. Participants include Cookening ${ }^{6}$, which

5. www.ponlecaraalturismo.com

6. www.cookening.com 
offers "a unique moment combining authentic cuisine and great people at a unique place", by bringing individual diners together with hosts in the city who will share a meal with them. Cookening aims to develop "cultural exchange through cooking", with tourists receiving an 'authentic' gastronomic experience created by locals. The Creative Paris programme was extended to the whole country in 2014 through the Creative France initiative?

On a smaller scale, the Dutch city of 's Hertogenbosch (Den Bosch) provides an example of how creativity can be used to develop tourism and to put a city on the map. In the case of Den Bosch, a creative approach to tourism development was necessitated by a lack of tangible heritage. Although the city has a well preserved historic inner city, it lacks tangible links to its most famous inhabitants, the medieval painter Hieronymus Bosch. Although the painter lived in the city most of his life, his paintings were scattered around the world, leaving no visible trace of his life and works in Den Bosch. This meant that Bosch was largely ignored as an icon for the city, particularly in marketing terms (Richards and Palmer, 2010: Marques, 2013). When the city recently decided to rediscover its forgotten son, therefore, one large obstacle remained - how to develop a cultural icon in the absence of tangible cultural heritage? The strategy adopted by Den Bosch was extremely creative. They developed a major event around the $500^{\text {th }}$ anniversary of the painter's death, and as part of this they started the Bosch Cities Network. This was a network of all the cities that owned paintings by Bosch, with, of course, Den Bosch (even though it had no paintings) as its hub. By offering to use the knowledge of Flemish paintings available in the city and the Netherlands to restore paintings in the other cities, Den Bosch managed to leverage the loan of a number of extremely important works for a major exhibition in 2016. This event attracted 421,700 visitors, generating a direct economic impact in excess of 100 million and media coverage to the value of over 20 million (Duif, 2016).

\section{Public-private partnership}

Creative Tourism Santa Fe (santafecreativetourism.org) is a programme offering a wide range of creative tourism experiences, from traditional quilting to landscape painting, pottery and three dimensional printing. The reputation of Santa Fe as a creative place helps to attract visitors to undertake creative activities, which in turn strengthens the cultural life of

7. www.creativefrance.fr 
the city and its branding. The programme is therefore partly financed by the City, but most of the experiences are provided on a commercial basis. It is estimated that the programme generated over $\$ 1$ million in sales for local artists in 2013 (Hanifl, 2015).

In Austria, a number of creative destinations have joined forces to develop 'Creative Austria', a marketing platform for the creative industries and tourism. They serve the cities of Salzburg, Graz, Vienna and Vorarlberg, getting funding from the city marketing offices of these destinations as well as generating commercial income by providing creative content for websites, magazines, in-flight channels and exhibitions.

\section{The way forward?}

Just as cultural tourism in the past, creative tourism has gradually moved from the fringes of the tourism industry to occupy a more central role in tourism markets and in the minds of policy makers. For destinations looking for sources of distinction in an increasingly crowded marketplace, creative tourism can potentially offer the 'edge' they desire.

One area of development that is outlined very clearly in the OECD report on Tourism and the Creative Economy (2014) is the growing integration of tourism and the broader creative industries. In some ways this has been a natural process, as films and literature have been taken up in destination marketing and development. However, there is also some evidence of more deliberate attempts to meld tourism and the creative industries in areas like fashion, design and gastronomy.

For example, in South Korea the success generated by the development of the 'Korean Wave' of TV and pop music in the past decade has now stimulated efforts to integrate tourism and the creative economy in a much more strategic way. Government policy encourages the development of joint policies targeting international markets and international visitors to Korea with live creative experiences, broadcasting of creative content and virtual creativity, particularly in areas such as animation. The growing popularity of Korean culture stimulates tourism to Korea (which has grown much more rapidly than global tourism over the past five years), which in turn stimulates sales of Korean creative products in areas such as film, fashion and food.

The integration of culture and creativity is becoming particularly evident in the field of gastronomy. Food used to be seen as a basic necessity 
for tourists tired out from their treks around the heritage highlights of destinations. These days it has also become a major attraction in itself (OECD, 2012). Not only are star chefs such as Ferran Adria positioning themselves as creative entrepreneurs in the tourism field, but whole countries (such as Sweden) are turning themselves into 'food countries'. Food has effectively become another creative industry, in which aesthetic values and the generation of knowledge are just as important as the basic food products themselves.

In the context of cultural and heritage tourism, therefore, we are seeing a shift from tangible to intangible assets as the basis of tourism experiences (UNWTO, 2016). This does not mean that the tangible basis of tourism disappears, but rather that the intangible 'packaging' and content of such experiences will expand. In this way, the role of the tourism and heritage professionals will also change, as they have to deal with an expanding range of experiences. They will inevitably be joined by those creatives looking for a way to utilise their creative skills and knowledge in the field of tourism. It therefore seems likely that there will be a fundamental change in the nature of cultural tourism, in the same way as the cultural content of tourism expanded in the 1980s and 1990s, and the way in which experiences have expanded in the past decade. 


\section{References}

Binkhorst, Esther and Teun Den Dekker. 2009. "Agenda for Co-Creation Tourism Experience Research." Journal of Hospitality Marketing $\mathfrak{E}$ Management 18: 311-327.

Butler, R.W. 1990. "Alternative Tourism: Pious Hope or Trojan Horse?" Journal of Travel Research 28: 40-45.

Couret, Caroline. 2012. "Barcelona Creative Tourism." Journal of Tourism Consumption and Practice 4(2): www.tourismconsumption.org

Dahles, Heidi. 1998. "Redefining Amsterdam as a Tourist Destination." Annals of Tourism Research 25: 55-69.

Duif, Lian. 2016. "De magie van Bosch: Oude schilders, nieuwe citymarketing." MMNieuws September 13: www.mmnieuws.nl/article/ de-magie-van-boschoude-schilders-nieuwe-citymarketing/

ETC. 2005. City tourism $\mathcal{E}$ culture: The European experience. Brussels: European Travel Commission.

Florida, Richard. 2002. The Rise of the Creative Class: And How It's Transforming Work, Leisure, Community and Everyday Life. New York: Basic Books.

Hanifl, Brent. 2015. What is the economic value of Creative Tourism in Santa Fe, New Mexico? MA Thesis, Degree of Masters of Science in Arts Management, University of Oregon.

Hewison, Robert. 1987. The Heritage Industry: Britain in A Climate of Decline. London: Methuen.

Hjalager, Anne-Mette and Greg Richards. 2002. Tourism and Gastronomy. London: Routledge.

Hung, Wei-Li, Yi-Ju Lee, and Po-Hsuan Huang. 2016. "Creative experiences, memorability and revisit intention in creative tourism." Current Issues in Tourism 19(8): 763-770.

Ilincic, Milica. 2014. "Benefits of Creative Tourism - The Tourist Perspective." In Greg Richards and Paolo Russo, (eds.) Alternative and creative tourism: 99-113. Arnhem: ATLAS.

Jusztin, Márta. 2012. "Creativity in the JoHari window: An alternative model for creating tourism programmes." Journal of Tourism Consumption and Practice 4(2): www.tourismconsumption.org

Lash, Scott and John Urry. 1994. Economies of Signs and Space. London: SAGE.

MacCannell, Dean. 1976. The Tourist. A New Theory of the Leisure Class. Davis: University of California Press.

MacManus, Paulette. 2000. Archaeological Collections and Display. London: University of London Press. 
Marques, Lenia. 2013. "Constructing Social Landscape through Events: The Glocal Project of 's -Hertogenbosch." In Greg Richards, Marisa de Brito and Linda Wilks (eds.), Exploring the Social Impacts of Events: 84-94. London: Routledge.

Messineo, Eliana. 2012. "Tourist creative processes and experiences in the European Cultural Itinerary. 'The Phoenicians' Route'." Journal of Tourism Consumption and Practice 4(2): www.tourismconsumption.org OECD. 2009. The Impact of Culture on Tourism. Paris: OECD.

OECD. 2012. Food and the Tourism Experience. Paris: OECD.

OECD. 2014. Tourism and the Creative Economy. Paris: OECD.

Pine, B. Joseph. and James H. Gilmore. 1999. The Experience Economy. Cambridge: Harvard University Press.

Raymond, Crispin. 2007. "Creative Tourism New Zealand: The practical challenges of developing creative tourism." In Greg Richards and Julie Wilson (eds.), Tourism, Creativity and Development: 145-157. London: Routledge.

Richards, Greg. 1996. Cultural Tourism in Europe. Wallingford: CAB International.

- (ed.). 2001a. Cultural Attractions and European Tourism. CAB International, Wallingford.

2001b. "The experience industry and the creation of attractions." In Greg Richards (ed.) Cultural Attractions and European Tourism: 55 69. CAB International, Wallingford.

(ed.). 2007. Cultural Tourism. Global and local perspectives. New York: Haworth Press.

- 2011. "Creativity and Tourism: The State of the Art." Annals of Tourism Research 38: 1225-1253.

. 2013. "Creativity and tourism in the city." Current Issues in Tourism 17(2): 119-144.

Richards, Greg and Lenia Marques. 2012. "Exploring Creative Tourism". Journal of Tourism Consumption and Practice 4(2): www. tourismconsumption.org

Richards, Greg and Robert Palmer. 2010. Eventful Cities: Cultural management and urban revitalisation. London: Routledge.

Richards, Greg and Crispin Raymond. 2000. "Creative Tourism." ATLAS News 23: 16-20.

Richards, Greg and Julie Wilson. 2006. "Developing Creativity in Tourist Experiences: A Solution to the Serial Reproduction of Culture?" Tourism Management 27(6): 1209-1223.

2007. Tourism, creativity and development. London: Routledge. 
Ritzer, George. 1999. Enchanting a Disenchanted World. Revolutionizing the Means of Consumption. Thousand Oaks: Pine Forge Press.

Russo, Antonio Paolo. 2002. "The 'Vicious Circle' of Tourism Development in Heritage Cities." Annals of Tourism Research 29: 165-82.

Tan, Siow-Kian, Ding-Bang Luh and Shiann-Far Kung. 2014. "A taxonomy of creative tourists in creative tourism." Tourism Management 42: 248259.

Turok, Ivan. 2009. "The distinctive city: pitfalls in the pursuit of differential advantage." Environment and Planning A 41(1): 13-30.

UNWTO. 2016. Report on Tourism and Culture Synergies. Madrid: UNWTO. Wurzburger, Rebecca, Alex Pattakos and Sabrina Pratt (eds.). 2009. Creative Tourism: A global conversation. Santa Fe: Sunstone Press. 